\title{
Intangible heritage of Icelandic equestrianism: the experience of domestic horse tourists
}

Le patrimoine immatériel de l'équitation islandaise : l'expérience des touristes domestiques à cheval

\section{Guðrún Helgadóttir and Ingibjörg Sigurðardóttir}

\section{OpenEdition}

\section{Journals}

Electronic version

URL: http://journals.openedition.org/tourisme/3208

DOI: 10.4000/tourisme.3208

ISSN: 2492-7503

\section{Publisher}

Éditions touristiques européennes

\section{Electronic reference}

Guðrún Helgadóttir and Ingibjörg Sigurðardóttir, "Intangible heritage of Icelandic equestrianism: the experience of domestic horse tourists", Mondes du Tourisme [Online], 18 | 2020, Online since 01 March 2021, connection on 15 March 2021. URL: http://journals.openedition.org/tourisme/3208 ; DOI: https://doi.org/10.4000/tourisme.3208

This text was automatically generated on 15 March 2021.

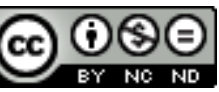

Mondes du tourisme est mis à disposition selon les termes de la licence Creative Commons Attribution - Pas d'Utilisation Commerciale - Pas de Modification 4.0 International. 


\title{
Intangible heritage of Icelandic equestrianism: the experience of domestic horse tourists
}

\author{
Le patrimoine immatériel de l'équitation islandaise : l'expérience des touristes \\ domestiques à cheval
}

Guðrún Helgadóttir and Ingibjörg Sigurðardóttir

\section{Introduction}

1 Through the ages, humans have valued horses, both for their economic role as well as for the cultural and social significance of the horse-human relationship. The relationship that humans have with horses has a long legacy of intangible heritage. This heritage includes the traditions of breeding, training and riding horses, beliefs and myths about horses and the values of equestrianism. These differ significantly in time and space depending upon what the horse-human relationship entailed: work, leisure and warfare leave different legacies.

2 Here, we focus on the intangible heritage of equestrianism in Iceland and on domestic equestrian tourism. For context the geographical location of Iceland is in the subarctic, the country is a volcanic island on the Atlantic ridge just touching the Arctic Circle. The terrain is rough, the vegetation alpine and the soil prone to erosion, with the country being partly covered with young lava fields. Iceland was and still is sparsely populated, with settlement occurring mainly in the coastal lowlands and much of the highlands remaining unsettled.

The humans who settled in Iceland came from the Nordic region and the British Isles during the late Viking era, in the $9^{\text {th }}$ century $\mathrm{AC}$, and it has been assumed, based on historical data, that the horses came from the same area (Aðalsteinsson, 2001; Hreiðarsdóttir and Hallsson, 2007). Genetic studies to investigate the origin of ambling horses suggest that the Icelandic horse stems from the British Isles during Iceland's 
settlement period (Wutke et al., 2016). The Icelandic horse is a gaited horse; in addition to the three basic gaits, walk, trot and gallop, the majority of the Icelandic horses have tölt and pace (Björnsson and Sveinsson, 2006; Stefánsdóttir et al., 2017). The ambling or gaited horse is a more comfortable riding horse and this was a highly valued quality, especially for long distance travelling.

Figure 1

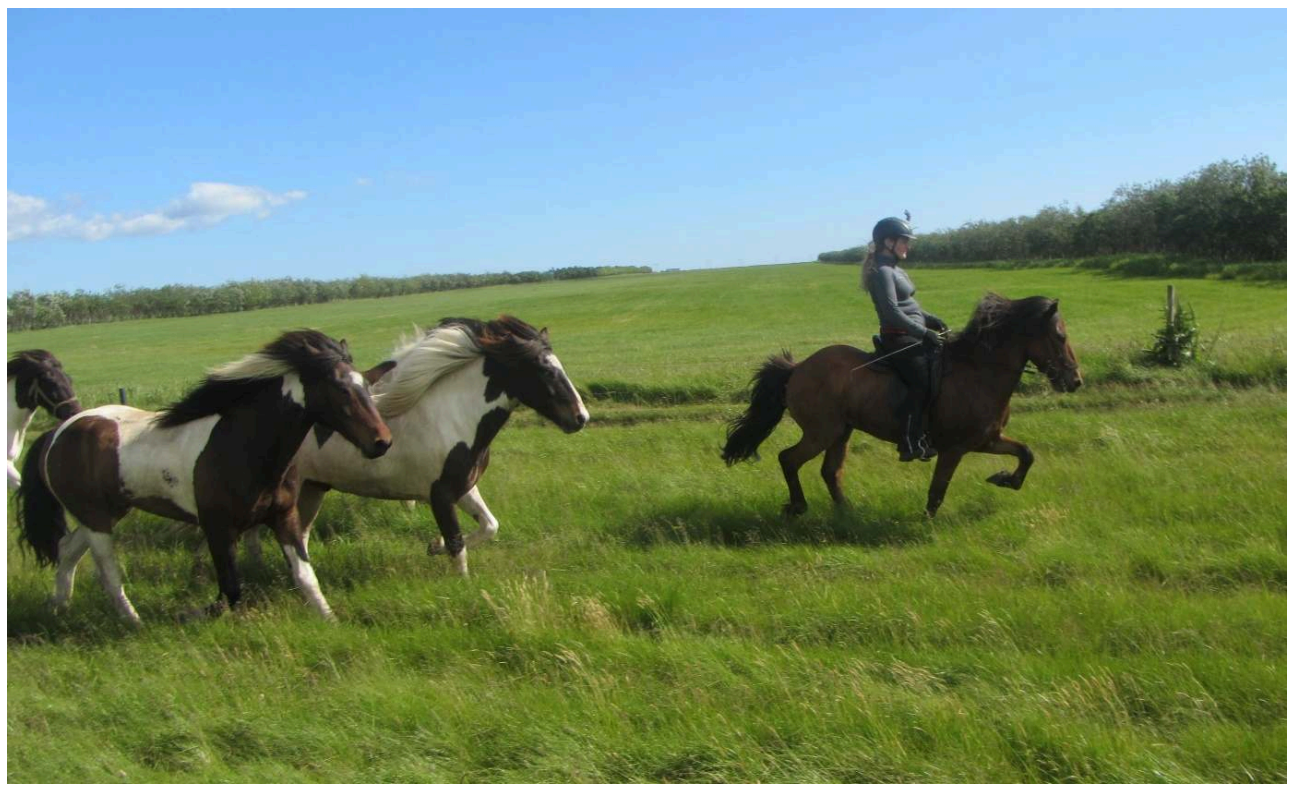

On long rides it is a pleasure to find paths that lend themselves to riding the tölt, a four beat lateral gait that is preferred by many riders.

Image by Ingibjörg Sigurðardóttir

In terms of the physical attributes of the Icelandic horse, the average height at the withers is about $140 \mathrm{~cm}$ (Kristjansson et al., 2016). The Icelandic horse grows a winter coat (Mejdell and Bøe, 2005); in addition, it sports a wide variety of colours: 11 main colours with many variations (Aðalsteinsson, 2001; Eypórsdóttir \& Dýrmundsson, 2004).The Icelandic horse is a popular riding horse found in more than 30 countries, but registered Icelandic horse clubs exist in 22 member countries of the FEIF - The International Federation of Icelandic Horse Associations (FEIF, 2020). In Iceland, the horse is at the heart of the equestrian tourism industry, where there are around 160 businesses offering both domestic and international visitors short and long riding tours that explore the natural Icelandic terrain (Sigurðardóttir, 2018).

Icelandic equestrian tourism has been a subject of research in recent years. This research includes the focus on the supply and demand sides of the industry, horse events, cluster development and future innovation opportunities (Helgadóttir, 2006, 2015, 2019; Helgadóttir and Sigurðardóttir, 2008, 2018; Sigurðardóttir and Helgadóttir, 2006, 2015a, 2015b; Sigurðardóttir and Steinpórsson, 2017, 2018; Schmudde, 2015; Sigurðardóttir, 2015, 2016, 2018; Helgadóttir and Daspher, 2016; Daspher, Helgadóttir and Sigurðardóttir, 2021). As part of the demand side of the equestrian tourism industry, the experience of guests in equestrian tourism businesses has been a subject of research in recent years (Sigurðardóttir and Helgadóttir, 2006, 2015a). However, another field of equestrian tourism, which is an intangible horse heritage, the travel of domestic riders on their own horses, has not been a subject of much research. 
The research addressed the following questions:

- What role does intangible heritage play in the domestic equestrian tourist experience of travelling with one's own horses and a group of human friends for several days in Iceland?

- In what way has the heritage of travelling with own horses in Iceland affected the conservation and use of ancient trails?

7 This article will start by discussing the theoretical background of tourism, experience and horse heritage, particularly the notion of native horses. The Icelandic horse and Icelandic equestrianism will then be addressed, before describing the research methods used. Findings will be introduced and discussed, and finally, conclusions will be drawn.

\section{Tourism, experience and heritage}

8 The horse and its power have fascinated people for centuries. The horse has been prominent in poetry, arts and culture (Helgadóttir, 2006; Pickel-Chevalier, 2017). It has been worshipped as a god and has commonly had a higher status in societies than other species of animals (Björnsson and Sveinsson, 2006). The status of the horse in contemporary cultures has been a subject of recent discourse. "Not quite a pet, yet certainly a more intimate companion than agricultural livestock, the modern sport horse holds a unique position in the human-animal dynamic" (Henderson, 2018, p.163). The bonding of humans and horses are in many ways similar to the bonding of pets and humans, but because of the size of the horse, it does not share human domestic space (Young \& Carr, 2018). The importance of seeing horses as travel companions has recently been highlighted, as multispecies holidays are becoming part of the humananimal relations discussion (Daspher, 2020).

Free-time and leisure can be defined as a premise for travel in recreational purposes. Expectations are developed before the travel, but customers' experience and satisfaction are highly affected by a number of factors, including how valuable the service is to the customer. Free time, leisure and tourism are associated with quality of life issues as they create opportunities for people to have a break from everyday life, to relax and do something different in a new environment (Page, 2009). The concepts of leisure and recreation in tourism are sometimes used as synonyms. Page and Connell (2009) describe the relations of those concepts in the following way:

Leisure is viewed as the time, activities and experiences derived, characterized by freedom to spend one's free time. Recreation is about the activities undertaken in one's leisure time leading to renewal. (Page and Connell, 2009, p.9)

10 By those definitions, activities such as equestrian tourism can be defined as recreation which takes place in the leisure time of individuals. Tourists' experience of leisure activities is affected by different factors. Pine and Gilmore (1999) presented the experience economy as a new paradigm to enhance business performance. Expectations, experience and customer satisfaction are highly related factors and basic terms in analysing tourism services (Zeithaml, Bitner and Gremler, 2013). Tourists do carry with them their norms, perceptions, standards and expectations, based on their personal experiences and backgrounds (Sharpley, 2018). Expectations of customers have developed and an increasing number of tourists are seeking special kinds of experiences (Oh, Fiore and Jeong, 2007), often with a focus on authenticity where cultural heritage tends to play a significant role (Park, Choi \& Lee, 2019). The extensive role of heritage within tourism and as an element of the tourist experience should not 
be neglected. Examples of that have been identified within the field of equestrian tourism (Helgadóttir, 2006; Pickel-Chevalier, 2019).

In many countries, horses are currently a significant tourist attraction and an important part of national identity and image (Beeton, 2001; Helgadóttir, 2006; Helgadóttir and Sigurðardóttir, 2008; White, 2011; Schmudde, 2015; Helgadóttir and Dashper, 2016; Leinonen and Dalke, 2017). Horses have been used as destination branding for tourism in countries like Australia, Canada, Finland, France, Hungary, Ireland and Iceland (Buchmann, 2014). White (2011) describes how important horses have been in the history and culture of Australia since settlement and how their importance has been transferred into the tourism industry and sports. In other parts of the world, horses are also an important part of tourism and destination identity, such as in Mongolia (Buckley, Ollenburg and Zhong, 2007) and Kyrgyzstan (Sturød, Helgadóttir and Nordbø, 2019).

Various horse-based activities have been defined as intangible cultural heritage by the United Nations Educational, Scientific and Cultural Organization (UNESCO). The word 'horse' yields 95 hits on the world heritage list of United Nations Educational Scientific and Cultural Organization. These range from cultural landscapes created for the breeding and use of particular horse breeds to stud farms, archaeological sites, petroglyphs, burial sites, trails and routes. The list of intangible heritage has 57 entries for 'horse', such as French Equitation, horse herding in Mexico, spring rite festivities of Kazakh horse breeders, nomadic traditions of horse breeding in Central Asia, the Kok Buro horse game from Kyrgyzstan, and Chogan from Iran, and the classical horsemanship of the Spanish Riding School Vienna, (n.d.). In 2011, horse riding in France was put on the representative list of the intangible cultural heritage of UNESCO (Grenet, 2012). Opportunities for tourism development have been identified in relation to horses and horse-based activities that are included in the UNESCO list of intangible cultural heritages, for example in France (Pickel-Chevalier, 2015, 2019).

the horse heritage lies in the horse breeds themselves. Both in terms of the qualities that breeders have favoured and brought forth through the selection of stallions and brood mares, and in terms of the traditions that have formed around horse husbandry. Native horse breeds do exist worldwide. Horsemanship and equestrian tourism based on native breeds has been described in Europe (Evans, Sigurðardóttir and Helgadóttir, 2015; Evans, 2015; Schuurman, 2017) and other parts of the world, like in Nepal (Wilson, 1997), Ethiopia (Kebede, 2020), Mongolia (Buckley, Ollenburg and Zhong, 2007) and Kyrgyzstan (Cassidy, 2009; Nordbø and Kyzy, 2014; Sturød, Helgadóttir and Nordbø, 2019).

Schuurman (2017) says that a native breed has a coherent history of a nation. "Horses are given a specific status as nationally valued breeds, essentially different from other breeds with a similar background" (p.121). Sturød et al. (2019) show how the notion of a national horse breed, a Kyrgyz horse, parallels the nation building strategies of postSoviet Kyrgyzstan. The same may be said of the Icelandic horse, as part of the promotion is the notion that Icelandic nature shapes the breed, along with the structured work of horse breeders (Helgadóttir, 2006).

15 Native breed horse tourism has gained attention as a form of equestrian tourism offering possibilities to create a new social and economic basis for keeping native breed horses in rural areas (Evans, Sigurðardóttir and Helgadóttir, 2015; Evans, 2015). 
To many of us, native breeds represent something different from the purebred equine breeds developed for sport and leisure riding in Europe during the last two to three centuries. Their association with their homelands and native landscapes mark them as special, and the term "native breed" suggests a naturalness removed from the conscious, "civilized", aristocratic breeding programmes of the $18^{\text {th }}$ and $19^{\text {th }}$ centuries in Europe. (Evans, 2015, p.206).

\section{Icelandic equestrianism: a living cultural heritage and leisure activity}

16 The horses were brought to Iceland on ships and were a precious cargo. Legend has it that the mare Fluga escaped upon landing and a settler bought her for a high price in the hopes of finding her alive (Pálsson and Edwards, 2014). While the medieval literature of Iceland, the Sagas, contain many accounts of the precious riding horses of the chieftains, the horse was also a worker. The Icelandic horses were trained to navigate a rough terrain (Helgadóttir, 2006; Helgadóttir and Sigurðardóttir, 2008, 2018). When there was occasion for recreation, the horse was usually involved. The most common horse-based leisure activities, or horse-based entertainment, in times of settlement could include a horse fight or spontaneous racing in through the natural landscape, later riding to church and the rare opportunity of an evening ride out. These precious leisure hours for horses and humans were cherished to such an extent that horses were also common subjects in poetry, literature and the visual arts (Björnsson and Sveinsson, 2006).

Leisure or free time was a privilege of the few in the farming society before the industrial revolution. With increased productivity, better economic conditions and shorter working hours, more people could afford to take time off from work to practise recreational activities in their leisure time (Sharpley, 2018). For many, the horse was, however, still a beast of burden and a symbol of the past where the everyday hard work literally called for horsepower. The new reality of industrialisation meant that machines of different kinds took over much of the toil of working horses and working people. At this point, where breeding horses for work became redundant, few saw breeding of native breeds such as the Icelandic horse as important (Björnsson and Sveinsson, 2006).

The Icelandic tradition is that horses are outside year-round, with the exception of riding horses that are in training and used in the wintertime. In Icelandic horses, Mejdell and Bøe (2005) found the maximum average coat length in December to be $46.3 \mathrm{~mm}$; shedding started in March, and minimum coat length in June was $5.0 \mathrm{~mm}$. From their study of a herd of Icelandic horses that spent $70 \%$ of their time outside: "It is concluded that a cold climate with temperatures down to $-31^{\circ} \mathrm{C}$ does not challenge the thermoregulation of cold-acclimated Icelandic horses, provided that there is sufficient quality feed and access to a shelter" (Mejdell and Bøe, 2005, p. 301). Today there are regulations stipulating that horses need access to feed, water and shelter all year-round (Lög um búfjárhald, 38/2013). In earlier times, most horses had to survive the winter without man made shelter and extra feeding. Back then, it was a sign of status to be able to keep and feed a riding horse in a stable during the winter (Björnsson and Sveinsson, 2006). 
19 240 horses per 1000 persons (Sigurðardóttir and Helgadóttir, 2015b), while in Sweden, the European Union country with the highest number of horses per person, the ratio was 32 horses per 1'000 persons in 2009 (Liljenstolpe, 2009). According to available figures on the number of horses compared to the population in EU countries, the ratio had dropped to 20.8 in 2018 (Statista, n.d.; Worldometers, n.d.). However, a more precise comparison is needed to state the trends and development in this regard. Given this high number of horses in Iceland and the long history of horse-human relations, the heritage of travelling by horse remains as an important element of the Icelandic culture.

Figure 2

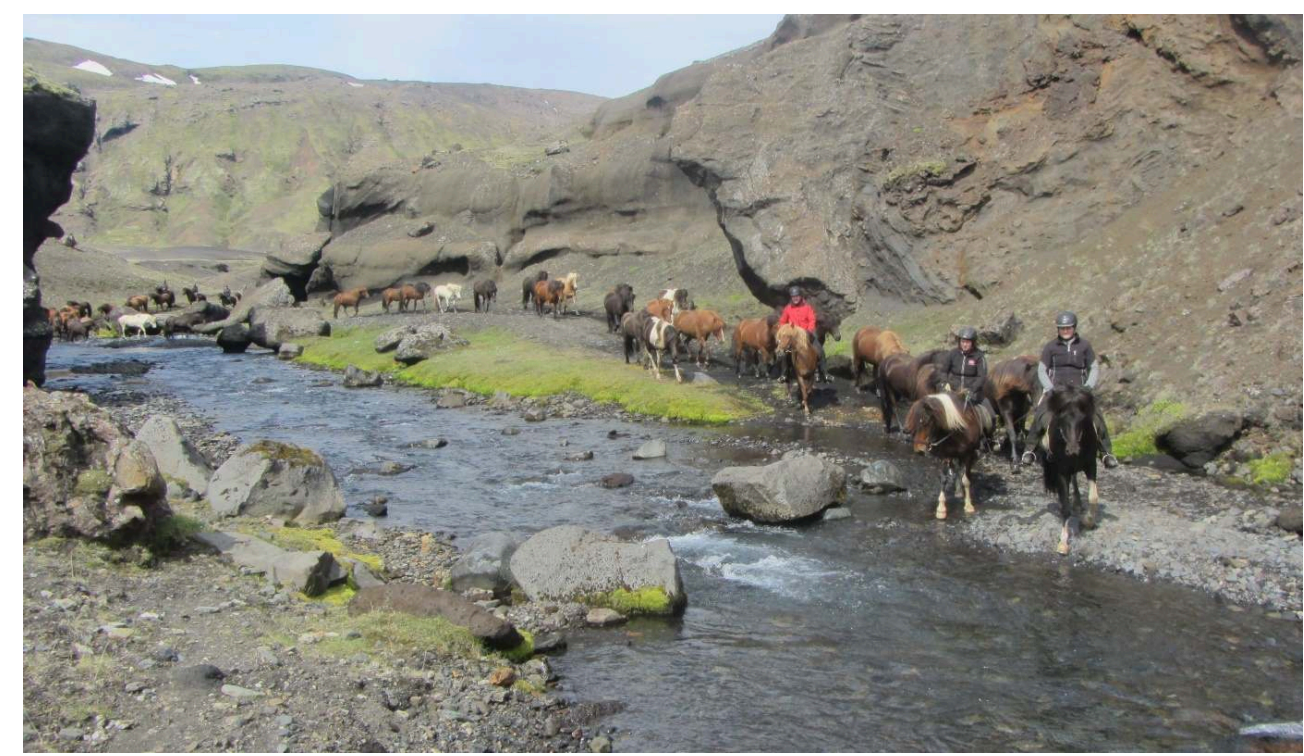

Travelling with a large group of horses is a common practice in Iceland.

Image by Ingibjörg Sigurðardóttir

In recent decades, human-horse relations have developed from horses and humans being co-workers in the everyday struggle for survival, to being companions in leisure and sports. Over recent decades, owning horses for recreational purposes has become popular and an important part of the worldwide equine industry (Eastwood, Jensen and Jordon, 2006). This has also been the case in Iceland, where the horse is important in leisure activities for both residents and international visitors. The journey from being the most needed servant to becoming a companion animal is not unique to the Icelandic horse as similar role changes happened with most horse breeds around the world over the last century (Pickel-Chevalier, 2017).

However, some horse breeds did not gain a new importance in contemporary postindustrial society, but rather they lost their pre-industrial economic role. This resulted in limited focus on breeding and maintenance of these breeds. This was the fate of Nordic horse breeds such as the Faroese horse and the domestic horse breeds in Norway: Fjord horse, Dala horse and Lyngs horse, all of whom have suffered a drastic decrease and the Faroese horse has been on the brink of extinction (Evans, Sigurðardóttir and Helgadóttir, 2013; Evans, Sigurðardóttir and Helgadóttir, 2015; Evans, Helgadóttir and Sigurðardóttir, 2017). Therefore, it is interesting in an 
international context to know more about the new role of the Icelandic horse developed in Iceland and abroad. Specifically, to know what this innovation and these new roles entail and how they are rooted in the intangible heritage of the horse-human relations in Iceland.

Today, equestrianism in Iceland is becoming more like European equestrianism with a high density of horses in the peri-urban areas. The contemporary equestrianism, based on the horse as a companion and the conditions for horse husbandry and equestrian sports in the peri-urban areas, are in many ways influenced by international standards of equestrianism. This is evident in the tangible heritage; the riding gear, bits, saddles, riding clothes and the stalls, the feed and use of treats are all examples of how the tangible heritage is changing in Iceland as elsewhere (Dashper and St John, 2016). An ever-increasing part of the nation has little opportunity to interact with domestic animals such as horses. This results in a knowledge gap around the qualities and conditions of these animals and the joint history of humans and horses.

Equestrianism is one of the biggest sports in Iceland; it is typically promoted as a family sport and the Icelandic horse as a good companion horse. Equestrian sports are but one side of the equestrian coin in Iceland. Travelling with a group of friends and a herd of horses for anywhere from two days up to a couple of weeks is a common summertime practice of domestic leisure riders in Iceland. During those long rides, various services are bought for humans and horses, including accommodation, meals and access to water and grazing for the horses (Sigurðardóttir and Helgadóttir, 2015b). When travelling on long rides it is common to have a group of riders in the lead, then a herd of free running horses, often up to around 100 at a time and then a few riders bringing up the rear (Helgadóttir, 2006). Often during the day, a car accompanies or meets the riding group occasionally. This is for both provisions and tack and for riders who need a break. The support driver also performs services such as putting up provisional fences, opening and closing gates and alerting other traffic to the riders and herd.

Domestic animals, mainly horses and sheep, have formed trails without direct human input and these are commonly used for riding through the Icelandic landscape (Helgadóttir and Sigurðardóttir, 2018). For domestic horse tourism, historical trails used through the centuries are also of great experiential value. Legends, literature, history and archaeological evidence contribute to a knowledge base that is a rich part of the equestrian heritage of Iceland (Jónsson, 1946). This heritage conjures up a cultural landscape allowing the rider to imagine the hoof beats of historic horses carrying heroes across the land. Closeness to nature, the wind in the horses' mane, the scent of vegetation and the sound of hoofs on the ground are sensory experiences that poets and writers have described eloquently (Ólafsson, 1900). This closeness to nature is no longer a given but a cherished opportunity for a nation that is increasingly urban.

Combining the natural experience of riding in Iceland with the slow adventure and the healing effects of horses, has been suggested as an opportunity for future development of equestrian tourism in Iceland (Sigurðardóttir, 2018). Many aspects of Icelandic equestrian tourism remain to be researched. This includes the experience of domestic riders travelling on their own horses on ancient trails, created by humans and domestic animals through the centuries, and the fact of this being part of the Icelandic heritage including the companionship of humans and horses through centuries.

26 This study focuses on domestic tourists in Iceland, travelling with their own horses around the country for several days at the time: in other words, tourists in their native 
country's natural settings, often riding historical trails. Before the tours, most horses have been trained for weeks, or even months, travelling routes have been organised and plans have been made on places for night stop overs for humans and horses. However, variable uncertainty factors exist as those tours commonly include 40-100 horses and about 5-20 riders. So, when travelling in a road-less landscape in different weather conditions, unexpected adventures may take place.

Figure 3

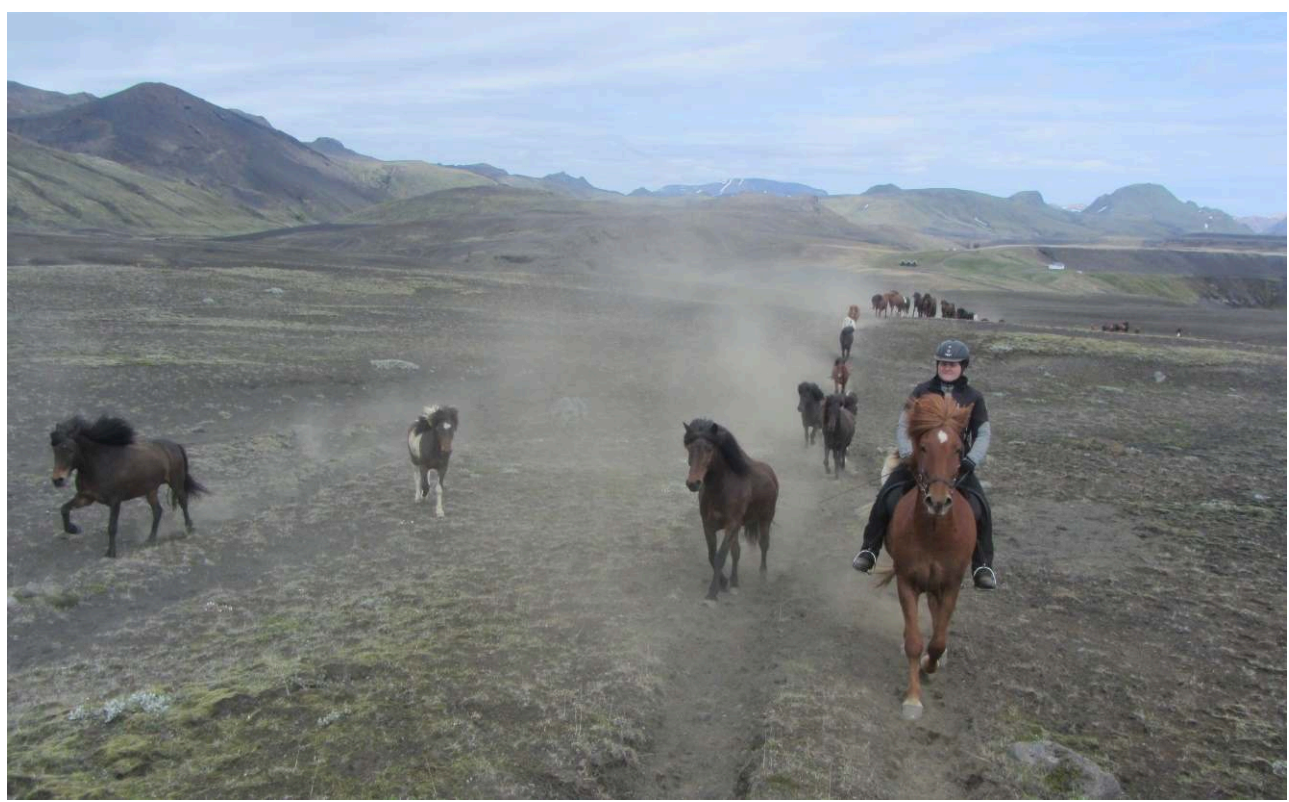

While most horses will fall into line travelling ancient trails in the Icelandic highland, it can be a challenge as humans and horses may not follow the beaten path.

Image by Ingibjörg Sigurðardóttir

\section{Methods}

The research methods used are a mix of participant observation, interviews and auto ethnographic accounts of travelling with horses in Iceland. It builds on the authors' long experience of travelling with their own horses and their experience of being tourists in their home country, often without prior knowledge of the exact travel destination beforehand. This personal experience and our years of research into equestrian tourism shaped our interview schedule. To bring this experience to light and analysis, we carried out an auto ethnographic account of our travel experience with horses.

Interviews are useful to learn about the opinions, attitudes and thoughts of people (Berger, 2016). More specifically Kvale and Brinkman (2009) state that "Interviews are particularly well suited for studying people's understanding of the meanings in their lived world, describing their experiences and self-understanding, and clarifying and elaborating their own perspective on their lived world" (p.116). To allow for elaboration and clarification, it is important to structure the interviews in a way that gives the respondents enough control to be able to say what they think in their own terms and context. Hence, we used semi-structured interviews (Berger, 2016). 
main data of this research were 11 semi-structured interviews with domestic horse tourists, whose experience of travelling with their own horses around Iceland in the summer ranges from a few years to several decades. Some of them were hobby riders, whereas others make their livelihood from the horse industry, e.g., as horse breeders and trainers (cf. table 1).

An interview frame/schedule, that is a list of questions and topics, was prepared and used to set the main focus of the interviews and to make sure they were all conducted in a similar way with all interviewees being asked similar questions. However, the interviews were flexible in that the questions were open-ended, inviting respondents to discuss the topics freely. "This cedes some control to the respondent over how the interview goes but because respondents are asked more or less the same questions this makes possible comparisons across interviews" (Bernard and Ryan, 2010, p.29).

31 Participants were granted anonymity so no citation can be traced back to an individual. The interviewed individuals are listed in table 1 as $\mathrm{P}$ (person) 1-11, where their gender, age and horse related profession is listed. Auto ethnographic accounts of the authors are listed as A (authors) 1-2.

Table 1. Demographics of respondents

\begin{tabular}{|l|l|l|l|}
\hline No & Gender & Age & Horse Profession \\
\hline P1 & female & $30-39$ & Horse breeder, hobby rider \\
\hline P2 & female & $40-49$ & Horse breeder, horse trainer \\
\hline P3 & male & $40-49$ & Horse breeder, riding instructor \\
\hline P4 & female & $60-69$ & Hobby rider \\
\hline P5 & female & $50-59$ & Hobby rider \\
\hline P6 & female & $50-59$ & Hobby rider \\
\hline P7 & male & $60-69$ & Hobby rider \\
\hline P8 & female & $60-69$ & Hobby rider \\
\hline P9 & female & $50-59$ & Horse breeder, hobby rider \\
\hline P10 & male & $50-59$ & Horse breeder, farmer \\
\hline P11 & female & $50-69$ & Horse breeder, horse trainer \\
\hline A1 & female & $60-69$ & Hobby rider \\
\hline A2 & female & $40-49$ & Horse breeder, hobby rider \\
\hline
\end{tabular}

As can be seen in table 1, only 3 out of 11 interviewees were male. As equestrianism is as much practised by male as female in Iceland, the gender balance should be more considered when further researching domestic equestrian tourism in Iceland. 

place in April to June 2018 when many horse riders were planning their tours for the summer, as long riding tours in Iceland take place in June to August. Interviews were recorded and transcribed before analysing. The first round of data analysis focussed on content, themes and topics predefined in the interview schedule. Those themes referred to tangible and intangible horse heritage, including the ancient riding trail (tangible heritage) and the history of horse travel (intangible heritage). In a second reading of the data, themes and topics emerging from the interviews were identified and investigated.

\section{Findings}

The questions posed in this study were:

- What role does intangible heritage play in the domestic equestrian tourist experience of travelling with one's own horses and a group of human friends for several days in Iceland?

- In what way has the heritage of travelling with own horses in Iceland affected the conservation and use of ancient trails?

In this research findings section, the focus is on how the tangible and intangible heritage of horse riding in Iceland has been transferred from earlier generations, whose livelihoods were based on agriculture where the horse was the most needed servant for transport and work, to the current tourism activity of domestic horse tourists in Iceland.

Traditions of travel with horses are an important intangible heritage of the horsehuman relation. The experiences described in the empirical material in this study are not similar to contemporary urban equestrianism. Rather, they conform to the Icelandic heritage of travelling long distance with horses using the trails created by humans, horses and sheep over the centuries. This intangible heritage of long rides in the summer, travelling long distances with groups of horses and people is for many equestrians in Iceland, the absolute peak experience - what interviewees work toward with their horses all year. In a sense, you could say that the long ride is what could transmit the intangible heritage of Icelandic equestrianism into the contemporary equestrianism in Iceland. The values of bonding with and understanding horses, nature and cultural landscapes, where the history is latent in the land, are at the core of this intangible heritage.

\section{Experiencing the lay of the land}

37 The difference in experiencing travel on horseback, on foot or by car is pointed out (P5; A2), particularly in relation to how people experience nature through these different ways of travelling. The different view, the perspective on the landscape, the speed, the smell, the movement and the atmosphere are all mentioned as distinguishing factors. It is suggested that when riding a horse, you get a wider perspective, the landscape becomes more visible, however, you pay less attention to features such as plants as compared to when walking. On horseback you have a $360^{\circ}$ view, unlike the view you have when driving, for example. The different speed of travelling on foot, by horse and by car is also mentioned as a factor which highly affects the experience. The same is highlighted regarding the smells experienced during travel; when walking you can

Mondes du Tourisme, 18 | 2020 
smell the soil and the plants, but when travelling by horse you also smell the horse and the tack. Through the ages, travellers have shared these sensations and they form a memorable and important part of the overall experience of horse travel. In contrast, the smell of the car interior, fuel and exhaust fumes are not suggested to play a positive role in the experience of travelling by car. Here the respondent is reflecting on travelling with horses as a more authentic, traditional way of travelling. However, travellers less interested in horses might find the smell of cars more attractive than the smell of horses (A2).

Ancient trails, which were used for centuries, are seen as an important element of the experience of travelling with one's own horses. Knowing the history of the trail, and that your ancestors travelled the same trail before you, is valuable for the domestic horse traveller (A2). Trails are part of the overall experience of riding for several days with a group of horses and human friends. Some interviewees describe the experience as being unreal. As P2 claimed: "Riding on a good trail on a good horse is close to an absolute bliss. There is no better way to forget about the daily struggle, become connected to nature and forget about everything else". Here the tangible heritage of the trail and the intangible sensation of interspecies connection with the land is at the core of the experience.

For the rider, the long ride is also a learning experience in negotiating different situations and challenges, such as rivers, lakes and steep mountains, and learning to trust the horse in navigating the terrain. Chasing horses that run in the wrong direction, horses losing their shoes, riders falling off their horses and other incidents do not seem to ruin the positive experience of the participants of this study. "I was in tears, the road was so rough and my husband had fallen into a pit and was covered in mud and then the girl riding in front of me turns around with this huge smile and shouts: Isn't this fantastic! We just had to laugh" (A1). Such events become the stuff of the good stories and tall tales that are very much part of the intangible heritage, the oral tradition of transmitting knowledge and values of Icelandic equestrianism, where being able to navigate challenging terrain with your horse is a mark of excellence.

\section{Human, horse and nature}

This unity of humans, horses and nature is commonly described by the interviewees and seems to be an important element of the intangible heritage of long rides in the Icelandic nature. "In those circumstances, human, horse and nature are one and everything else is forgotten. This is rejuvenating for body and soul even though the ride is demanding" (P2). This is further described by another interviewee saying: "Horse and human connect and enjoy the travel. You get to know your horse in a new way and you keep this in your mind to warm your heart on cold winter nights. The feeling of gliding over a grassy meadow on a soft 'tölt' is a peak moment" (P3).

41 The riding tour being something memorable and having long lasting effects is further described in the following way: "The warmth from your friend with the beautiful brown eyes [...] will never be forgotten" (P5). These experiences of interspecies affection, equestrian love and respect for the horse, as described in our research, are also found in film and literature (ólafsson, 1900; Gunnarsson, Björgúlfsson and Ingimarsson, 2004; Gunnarsson, Karlsson and Björgúlfsson, 2009). To understand the 
intangible heritage of Icelandic equestrianism, it is important to realize that the core value is interspecies respect and care for the horse.

Equestrian tourism can be seen as a revitalisation of traditional horse travel in Iceland. Through centuries, riders have taken into account the capability and strength of their horses and the nature of the terrain as a part of planning their travel. On tours that last several days, different kinds of trails and riding conditions are chosen for different horses. The young horses are ridden at the shortest and easiest legs of the ride, whereas the older and more experienced horses are ridden in more demanding conditions. The gaits of each horse, its age, experience and training conditions are among the factors affecting what kinds of trails are most suitable for each horse. The willingness of each horse also affects whether they are ridden in the lead or in the back of the herd. For example, if a horse is not eager to go forward, it is preferably ridden at the back of the herd, as it will not want to be left behind. This can be a source of dissent between horse and rider in case that the horse wants to keep up but the rider wants to stay at the rear (A1; A2).

It is particularly important to carry forth the equestrian heritage from the times when horse-human relations were part of everyday life, into a contemporary urban equestrianism where the time of horse and rider are more tightly circumscribed. It is suggested that young horses learn new things and start expressing new qualities. In most cases, these are positive, reflecting that they are increasing their skills and riding abilities during these long rides. This gives the rider/trainer a reward and positive feeling for the development of the young horses as "the horses become light and positive and fun to ride. Everybody [humans and horses] are feeling good" (P1). Long horse travel is an opportunity to get to know the horse's good qualities. Using long rides in the training of these qualities is an important notion in the intangible heritage of Icelandic equestrianism.

\section{The stuff of stories and songs}

In some groups, it is customary to sing and recite poems and stories relating to the trail and even create new songs and stories. It is customary, when travelling by horse, to sign the guestbook of the cabins and houses where you stay and most of them will have one. Typically, someone from the group will write a short note on how many horses the group travels with, the route taken to this destination, how it went and where they are headed next, as well as giving thanks for the accommodation. These accounts are sometimes embellished with spontaneous illustrations of the horses and riders, or with short poems written for the occasion (A1; A2). The custom is that the whole group signs their names. This is an important tradition of documenting the intangible heritage of the long ride in Icelandic equestrianism.

Within the group of friends, the events of the long rides become oral heritage, in most cases also supported by photographs, although the most exciting and dramatic events are seldom documented in the heat of the moment, however, creating a memorable tourist experience. These often have to do with the safety and wellbeing of humans and horses, as travelling through the natural landscape throughout history has required facilities for human and non-human travellers. Small fences or corrals are needed to be able to stop with a herd of horses and relax for a while without being worried about the horses running away. Good facilities for horses when staying overnight, including 
access to water, feed and shelter, are seen by many as equal to or even more important than accommodation facilities for the human travellers. Being able to keep the horses at the same place as the humans' overnight stop is emphasised, in order that an eye can be kept on the horses to ensure that they are safe and well. "On one of my first trips a more experienced friend always insisted on staying a while with the horses and I experienced why when my mare got colic and I would not have noticed if we had got in the car and driven off to the cabin where we were staying overnight" (A1).

Such events, when things went or nearly went wrong, are kept alive by recounting and some become part of the intangible equestrian culture, and from there even into mainstream cultural expression, such as the film of Horses and Men by Benedikt Erlingsson. The film uses old and new equestrian legends. The original title of the film is Hross í oss which literally translates as Horses in us, or as the director says it is "... about the human streak in the horse and the horse in the human" (Erlingsson, 2013).

\section{The ancient trail}

The respondents shared an interest in traditional trails or ancient trails, as these are a part of the cultural landscape. Riding trails are seen as an important attraction for riding tourists. The value of ancient trails was particularly addressed. Interviewee 4 said: "It is a lot of fun to investigate and experience ancient trails. The history really matters". Interviewee 5 further discusses the ancient trails, describing how those old trails are part of the landscape and are located where it is easiest to pass e.g. in rough landscape.

The skill of reading the land used to be an important part of travelling the highlands in Iceland and it remains important for the current tours, as during a ride you are not always riding demarcated trails. Interviewees, suggest that ancient trails can inform the rider about the nature, as well as the history and cultural landscape. The way the trail winds through the terrain depends partly on geoforms, partly on grazing and watering opportunities, shelter from weather and natural hazards. A swing in the trail can, for instance, indicate a dangerous element in the landscape, not visible to the rider. One of the interviewees told a story of ending up in a quagmire with her horse and being teased forever after by her riding companions with the question: "What is with you woman? Can't you read the lay of the land!" (P11). Author 1 had a different experience with quagmire while riding along a reservoir in the highlands. The horse tried several times to avoid a path closer to the waterfront that the author wanted to follow. Suddenly the horse is up to the flanks in mud and the rider on the ground. Fortunately, there was no lasting damage other than the embarrassment of not having respected the tradition of letting the horse sense rule, that a horse knows better than a human where to put its hoof.

Given that the ability to read the landscape maybe limited in contemporary society, it is noteworthy that the respondents were most interested in riding on natural substrata. Riding on asphalt is seen as bad for the wellness of horses as the surface is hard. Proximity to vehicle traffic is considered stressful and potentially dangerous for humans and animals. The interviewed tourists also prefer to ride well away from vehicle traffic, however, new riding trails in the lowlands are commonly located beside the road for motorised traffic. According to interviewee P2, the quality of a trail also depends on whether you are riding alone or with a group of horses, or even with a hand 
horse(s) (the rider leads one or more horses beside him), as travelling with hand horse(s) demands wider trails and more space than travelling with only one horse. "Some people see the trail as a scar on the face of earth and react to seeing many parallel trails especially in the highlands. For me they suggest that others have been here before me and my horse and made these trails, inviting me to follow" (A1).

Riding trails and their surroundings are not only important for the riders, but also for the welfare of horses during the journey. For centuries, resting places have been of importance for travellers, not least the ones travelling on horses. Easy access to grassland and water at regular intervals during the ride is important for the horses. Interviewee 1 (P1) says that when passing deserted land, the horses become less spirited and more tired and bored than when travelling in a grassy land where the horses can have something to eat and drink during their pauses. The danger of the horses breaking away from a corral or temporary enclosure is also greater if there is no grazing available.

51 The issue of landowners occasionally closing ancient trails was raised as a concern. The interviewees claim that the trails are heritage, elements in the history of the nation and an important infrastructure for equestrian businesses that wish to promote the intangible heritage of equestrianism in Iceland.

\section{Conclusions}

Various factors are of historical and contemporaneous importance in regard to tangible and intangible horse heritage. One is the landscape, both the cultural landscape created by generations of humans and animals (Helgadóttir, 2006), another is the sensory quality of the trail (Helgadóttir and Sigurðardóttir, 2018) and a third is the horsehuman relation, both kinaesthetic and mental.

The native Icelandic horse, the only horse in the country, is intertwined with the history of the nation and is important for the image of the country as a tourism destination (Helgadóttir, 2006; Schmudde, 2015), both for international and domestic guests. This research brings forth the importance of the equestrian heritage of travelling by or with horses in Iceland. The ancient trails are still used and cherished while new riding trails are made to make it possible to travel around the country for days or weeks. For the domestic tourists travelling on/with their own horses, the trails are important as they are seen as heritage, as evidence of the history and of the cultural landscapes created by previous generations. Access to riding trails is valuable for domestic tourists, as concerns about ancient trails being closed has been raised as one of the major challenges of the horse industry and horse travellers in Iceland (Helgadóttir and Sigurðardóttir, 2008, 2018). The historical value of riding trails and the heritage of horse riding around the country can play a significant role in ensuring that historical trails are kept accessible for riders to make use when travelling for leisure purposes and for developing tourism activities.

The unity of humans, horses and nature is strengthened when a herd of horses and a group of human friends and relatives travel together. The horses and humans are of all ages, as equestrianism is a sport and leisure activity that Icelanders of all ages and both genders enjoy. The core value of interspecies respect is an intangible heritage going back to the earliest accounts of horsemanship in Iceland, in terms of the recognition of the special native horse, of the close bond between horse and rider and the horses' 
ability to navigate the terrain and the trust placed in their sharp sense of the environmental conditions. What is new in our interviews is that some of our respondents talk more freely of their relationship with horses in terms that formerly were used primarily to describe human relations such as love and friendship.

While the humans are aware of the lasting effect of the long ride on their wellbeing, there is also a belief that the long ride is important for horses. It is emphasised that the horses become stronger and fitter through long rides than they do through shorter riding tours in familiar surroundings. In earlier days, when the horse served as both a means of transport and a beast of burden on farms, human-horse relations were strong as the horse was an important source of livelihood and companion in everyday life. Nowadays, this working relationship is not as visible and horsemanship commonly includes a ride of approximately 1 hour-long in length around 5 times per week. On the long ride, horses and humans bond, and young horses learn the ropes of travel. It is considered good training for the riding horse, making it stronger and more surefooted. For the rider, the long ride is the opportunity to really get to know the horse and strengthen communication, closer to how it was in earlier days. Also, it is an opportunity to become a tourist in your own country and to get away from the everyday strain and stress (Sigurðardóttir, 2018).

This research indicates that horse travel of domestic tourists in Iceland is an example of tangible and intangible horse heritage being transferred into the present, where it becomes a leisure activity based on history and cultural heritage. Through this, the history of horse riding goes on and new heritage can be created. This continuation can be a foundation for future development of horse-based activities, such as tourism, where the Icelandic horse heritage plays a significant role for future generations of humans and horses.

\section{BIBLIOGRAPHY}

Stefán AĐALSTEINSSON, Íslenski hesturinn - litir og erfðir [The Icelandic horse - colours and genetics], Ormstunga, 2001.

Sue BEETON, "The cost of complacency: Horseback tourism and crisis management revisited", Current Issues in Tourism, 5(5), 2001 [doi: 10.1080/13683500108667897].

Arthur Asa BERGER, Media and Communication Research Methods. An Introduction to Qualitative and Quantitative Approaches (4 ${ }^{\text {th }}$ edition), SAGE, 2016.

H. Russell BERNARD and Gery W. RYAN, Analyzing Qualitative Data. Systematic Approaches, SAGE, 2010.

Gísli B. BJÖRNSSON and Hjalti Jón sVEINSSON, Íslenski hesturinn [The Icelandic horse], Mál og menning, 2006.

Anne BUCHMANN, "Insights into domestic horse tourism: the case study of Lake Macquarie, NSW, Australia", Current Issues in Tourism, 2014 [doi:10.1080/13683500.2014.887058]. 
Ralf BUCKLEY, Claudia OLLENBURG and Linsheng ZHONG, "Cultural landscape in Mongolian tourism", Annals of Tourism Research, 35(1), 2008 [doi: 10.1016/j.annals.2007.06.007].

Rebecca CASSIDY, "The horse, the Kyrgyz horse and the 'Kyrgyz horse' ", Anthropology today, 25(1), 2009.

Katherine DASHPER, "Holidays with my horse: Human-horse relationships and multispecies tourism experiences", Tourism Management Perspectives, 34, 2020 [https://doi.org/10.1016/j.tmp. 2020.100678].

Katherine DASHPER, Guðrún HELGADÓTTIR and Ingibjörg SIGURĐARDÓTTIR (eds.), Humans, Horses and Events, CABI Publisher, 2021.

Katherine DASHPER and Michael ST JOHN, "Clothes make the rider? Equestrian competition dress and sporting identity", Annals of Leisure Research, 19(2), 2016.

Sharon EASTWOOD, Anne-Lise Riis JENSEN and Anna JORDON, Business Management for the Equine Industry, Blackwell Publishing, 2006.

Benedikt ERLINGSSON, "Of horses and men”, Film produced by Leiknar Myndir and Filmhuset gruppen, 2013.

Rhys EVANS, "Riding native Nordic breeds: native breeds as cultural heritage development in Nordic countries (Norway, Iceland, Scotland and the Faroe Islands)", Cheval, Tourisme \& Sociétés/ Horse, Tourism \& Societies, Mondes du tourisme, special issue, 2015.

Rhys EVANS, Guðrún HELGADÓTTIR and Ingibjörg SIGURĐARDÓTTIR, Håndbog i Hestetourisme [Handbook of horse tourism, Holiday riders' association], Foreningen FerieRytter [Holiday riders' association], 2017.

Rhys EVANS, Guðrún HELGADÓTTIR and Ingibjörg SIGURĐARDÓTTIR, A good practice guide to equine tourism. Developing native breed equine tourism in the North Atlantic region, Høgskulen for Landbruk og Bygdeutvikling, Hólar University College, 2015.

Rhys EVANS, Guðrún HELGADÓTTIR and Ingibjörg SIGURĐARDÓTTIR, Riding native Nordic breeds. Developing native breed equine tourism in the North Atlantic region, first year final report, Høgskulen for Landbruk og Bygdeutvikling, Hólar University College, 2013.

Emma EYDÓRSDÓTTIR and Ólafur DÝRMUNDSSON, Íslensk búfjárkyn - Icelandic livestock breeds - Islandske husdyrraser, Bændasamtök Íslands, 2004.

FEIF, FEIF facts and figures, Statistics about member associations: Clubs [https://www.feif.org/ FEIF/Factsandfigures/Clubs.aspx].

Árni GUNNARSSON, Steingrímur KARLSSON an Porvarður BJÖRGÚLFSSON, "Kraftur: Síðasti spretturinn” [Kraftur: The last ride], Film produced by Skottafilm, 2009.

Árni GUNNARSSON, Porvarður BJÖRGÚLFSSON and Ingimar INGIMARSSON, "Í Austurdal”, Film produced by Skottafilm, 2004.

Guðrún HELGADÓTTIR and Ingibjörg SIGURĐARDÓTTIR, "Horse-based tourism: Community, quality and disinterest in economic value", Scandinavian Journal of Hospitality and Tourism, 8(2), 2008 [doi: $10.1080 / 15022250802088149]$.

Guðrún HELGADÓTTIR and Ingibjörg SIGURĐARDóTTIR, “The riding trail as geotourism attraction: Evidence from Iceland", Geosciences, 8(10), 2018 [http://dx.doi.org/10.3390/geosciences8100376]. Guðrún HELGADÓTTIR, "Herding livestock and managing people. The cultural sustainability of a harvest festival", in J. Mair (ed.), The Routledge Handbook of Festivals, Routledge, 2019. 
Guðrún HELGADÓTTIR, "Horse roundups in Iceland: a harvest festival and a tourism attraction", Cheval, Tourisme \& Sociétés/Horse, Tourism \& Societies, Mondes du tourisme, special issue, 2015.

Guðrún HELGADÓTTIR, “The culture of horsemanship and horse-based tourism in Iceland”, Current Issues in Tourism, 9(6), 2006 [doi:10.2167/cit297.0].

Guðrún HELGADÓTTIR and Katherine DASHPER, “ 'Dear international guests and friends of the Icelandic horse': Experience, meaning and belonging at a niche sporting event", Scandinavian Journal of Hospitality and Tourism, 16(4), 2016 [doi:10.1080/15022250.2015.1112303].

Antonia J.Z. HENDERSON, "Pampered prisoners. Meeting the ethological needs of the modern sport horse to enhanced equine welfare", in Janette YOUNG and Neil CARR (eds.), Domestic Animals, Humans, and Leisure. Rights, Welfare, and Wellbeing, Routledge, Taylor \& Francis Group, 2018. Gunnfríður Elín HREIĐARSDÓTTIR and Jón Hallsteinn HALLSSON, “Uppruni íslenska hestsins”, Fræðaping landbúnaðarins 4 ["Origin of the Icelandic horse”, Proceedings of the Agricultural research conference 4], 2007.

Ásgeir Jónsson, Horfnir góðhestar 1946.

Alemu Alene KEBEDE, "Horse culture \& tourism development: Towards initiating horse tourism in Awi Zone, Northwestern Ethiopia", Cogent Social Sciences, 6(1), 2020 [https://doi.org/ 10.1080/23311886.2020.1735116].

Thorvaldur KRISTJANSSON, Sigridur BJORNSDOTTIR, Elsa ALBERTSDÓTTIR, Agust SIGURDSSON, P. POURCELOT, N. CREVIER-DENOIX and Thorvaldur ARNASON, "Association of conformation and riding ability in Icelandic horses”, Livestock Science, 189, 2016.

Steinar KVALE and Svend BRINKMANN, InterViews: Learning the Craft of Qualitative Research Interviewing, SAGE, 2009.

Riitta-Marja LEINONEN and Karen DALKE, "National treasure: nationalistic representation of the Finnhorse in trotting championships", in Miriam ADELMAN and Kirrilly THOMPSON (eds.), Equestrian Cultures in Global and Local Context, Springer, 2017.

Carolina LILJENSTOLPE, Horses in Europe, Swedish University of Agricultural Sciences, 2009.

Lög um búfjárhald nr. 38/2013 [38/2013 Act on livestock].

Cecilie M. MEJDELL and Knut E. BøE, "Responses to climatic variables of horses housed outdoors under Nordic winter conditions”, Canadian journal of animal science, 85(3), 2005.

Ingeborg NORDBø and Elvira S. KYZY, "Health tourism and horse milk therapy in Kyrgyzstan", in Melanie Smith and Lazlo Puczkó (eds.), Health, Tourism and Hospitality. Spas, wellness and medical travel, Routledge, 2014.

Haemoon OH, Ann Marie FIORE and Miyoung JEONG, "Measuring experience economy concepts: Tourism applications", Journal of Travel Research, 46, 2007 [doi: 10.1177/0047287507304039].

Páll óLAFsson, Ljóđmceli [Poems], II bindi, Aldar-prentsmiðja, 1900.

Stephen J. PAGE, Tourism Management. Managing for Change ( $3^{\text {rd }}$ ed.), Butterworth Heinemann, 2009.

Stephen J. PAGE and Joanne CONNELL, Tourism. A Modern synthesis ( $3^{\text {rd }}$ ed.), South-Western Cengage Learning, 2009.

Hermann PÁLSSON and Paul EDWARDS (eds.), Landnamabok (vol. 1), Univ. of Manitoba Press, 2014. 
Eunkyung PARK, Byoung-Kil CHOI and Timothy J. LEE, "The role and dimensions of authenticity in heritage tourism", Tourism Management, 74, 2019 [https://doi.org/10.1016/j.tourman.

2019.03.001].

Sylvine PICKEL-CHEVALIER, "Tourism and equine heritage in France: the case study of the Cadre noir de Saumur and the Vendée Stud", Current Issues in Tourism, 2019 [https://doi.org/ 10.1080/13683500.2019.1706459].

Sylvine PICKEL-CHEVALIER, "Globalization and equestrian culture: the case of equitation in the French tradition", in Miriam ADELMAN and Kirrilly THOMPSON (eds.), Equestrian Cultures in Global and Local Context, Springer, 2017.

Sylvine PICKEL-CHEVALIER, "Can equestrian tourism be a solution for sustainable tourism development in France?", Loisir et Société/Society and Leisure, 38(1), 2015 [doi: 10.1080/07053436.2015.1007580].

Joseph B. PINE and James H. GILMORE, "Welcome to the experience economy", Harvard Business Review, 76(4), 1998.

Rebekka SCHMUDDE, "Equestrian tourism in national parks and protected areas in Iceland. An analysis of the environmental and social impacts", Scandinavian Journal of Hospitality and Tourism, 15(1-2), 2015 [doi:10.1080/15022250.2014.1000713].

Nora SCHUURMAN, "The transnational image of the Spanish horse in the leisure horse trade", in Miriam ADELMAN and Kirrilly THOMPSON (eds.), Equestrian Cultures in Global and Local Context, Springer, 2017.

Richard SHARPLEY, Tourism, Tourists and Society (5 $5^{\text {th }}$ ed.), Routledge, 2018.

Ingibjörg SIGURĐARDÓTTIR, "Wellness and equestrian tourism: New kind of an adventure?", Scandinavian Journal of Hospitality and Tourism, 18(4), 2018 [https://doi.org/ 10.1080/15022250.2018.1522718].

Ingibjörg SIGURĐARDÓTTIR, "Lífstíll verður ferðavara; próun fyrirtækja í hestamennsku á Íslandi” [Lifestyle as a tourism product. Development of equestrian businesses in Iceland], Tímarit um viðskipti og efnahagsmál [Research in applied business and economics], 13(2), 2016 [https://doi.org/ 10.24122/tve.a.2016.13.2.1].

Ingibjörg SIGURĐARDÓTTIR, "Identifying the success criteria of Icelandic horse-based tourism businesses: interviews with operators", Cheval, Tourisme \& Sociétés/Horse, Tourism \& Societies, Mondes du tourisme, special issue, 2015.

Ingibjörg SIGURĐARDÓTTIR. and Guðrún HELGADÓTTIR, "Riding high: quality and customer satisfaction in equestrian tourism in Iceland", Scandinavian Journal of Hospitality and Tourism, 15(1-2), 2015 [doi: 10.1080/15022250.2015.1015765 2015a].

Ingibjörg SIGURĐARDóTTIR and Guðrún HELGADóTTIR, “The new equine economy in Iceland”, in C. Vial and R. Evans (eds.), The new equine economy in the $21^{\text {st }}$ century, Wageningen Academic Publishers, 2015b.

Ingibjörg SIGURĐARDÓTTIR and Guðrún HELGADÓTTIR, “Upplifun og pjónusta: Íslenskir gestir í hestaleigum" ["Experience and services: Icelandic customers in domestic horse rentals"], Landabréfið, 22(1), 2006.

Ingibjörg SIGURĐARDÓTTIR and Runólfur Smári STEINDÓRSSON, “Development of micro-clusters in tourism: a case of equestrian tourism in northwest Iceland", Scandinavian Journal of Hospitality and Tourism, 18(3), 2018 [https://doi.org/10.1080/15022250.2018.1497286]. 
Ingibjörg SIGURĐARDóTTIR and Runólfur Smári STEINPÓRSSON, "Establishment and downfall of a cluster initiative in Northwest Iceland", Contemporary Issues in Law, 14(3), 2017.

STATISTA, Number of horses in the European Union and the United Kingdom in 2018, by country (in 1,000s), n.d. [https://www.statista.com/statistics/414913/eu-european-union-number-ofhorses-by-country/, accessed September $\left.11^{\text {th }} 2020\right]$.

Guðrún J. STEFÁNSDÓTTIR, Víkingur P. GUNNARSSON, Sveinn RAGNARSSON and Anna JANSSON, "Physiological response to an experimental $100 \mathrm{~m}$ flying pace race in Icelandic horses and effect of rider", Comparative Exercise Physiology, 13(4), 2017.

Anne Gry STURøD, Guðrún HELGADóTTIR and Ingeborg NORDBø, “The Kyrgyz horse: enactments and agencies in and beyond a tourism context", Current Issues in Tourism, 2019 [https://doi.org/ 10.1080/13683500.2019.1626813].

UNESCO, Intangible World Heritage list, Search: Horse [https://ich.unesco.org/en/search-00795? $\mathrm{q}=$ Horse $\& \mathrm{p}=6$, accessed April $\left.14^{\text {th }} 2020\right]$.

Leanne WHITE, "The role of the horse in Australian tourism and national identity", in Elspeth FREW and Leanne WHITE, Tourism and National Identities, An International Perspective, Routledge, 2011.

R. Trevor WILSON, "Animal genetic resources and domestic animal diversity in Nepal”, Biodiveristy and Conservation, 1997.

WORLDOMETERS, Current World Population, n.d. [https://www.worldometers.info/worldpopulation/, accessed September $\left.11^{\text {th }} 2020\right]$.

Saskia WUTKE, Leif ANDERSSON, Norbert BENECKE, Edson SANDOVAL-CASTELLANOS, Javier GONZALEZ, Jón Hallsteinn HALLSSON, Lembi LOUGAS, Ola MAGNELL, Arturo MORALES-MUNIZ, Ludovic ORLANDO, Albína Hulda PÁLSDÓTTIR, Monika REISSMANN, Mariana B. MUÑOZ-RODRÍGUEZ, Matej RUTTKAY, Alexandra TRINKS, Michael HOFREITER and Arne LUDWIG, “The origin of ambling horses”, Current Biology, 26(15), 2016.

Jeanette YOUNG and Neil CARR (eds.), Domestic Animals, Humans, and Leisure. Rights, Welfare, and Wellbeing, Routledge, Taylor \& Francis Group, 2018.

Valarie A. ZEITHAML, Mary Jo BITNER and Dwayne D. GREMLER, Services Marketing, Integrating Customer Focus Across the Firm (6 ${ }^{\text {th }}$ ed.), Mc Graw Hill, 2013.

\section{ABSTRACTS}

Horses were previously known to be the most needed servants in the farming society in Iceland. The Icelandic horse, the only horse breed in the country, was part of everyday life for the inhabitants, serving as a means of transport and a work companion. Riding a horse or walking, were the only means of transport across Iceland's rough terrain up until the $20^{\text {th }}$ century. Tangible and intangible heritage related to horses is therefore strong in Iceland. This heritage has shown to be important for equestrian tourism businesses in Iceland, but the role of this heritage in the development of domestic tourists' leisure activities remains unstudied. This research looks into the role of intangible and tangible heritage in domestic horse tourists' experiences during long rides, that is travelling with their own horses and a group of human friends for several days. The research was conducted through a mix of participant observation, 11 interviews and auto ethnographic accounts of being a horse tourist in Iceland. The research indicates that tangible and intangible heritages related to horse translates into leisure activities of domestic riders, where the fact that the riders are following the footsteps of their ancestors 
along the ancient trails plays a significant role for these tourists. In this way, the equestrian heritage is lived and further developed for current and future generations of humans and horses.

Les chevaux étaient auparavant connus pour être les serviteurs les plus nécessaires à la société agricole en Islande. Le cheval islandais, seule race de chevaux du pays, faisait partie du quotidien des habitants, servant de moyen de transport et de compagnon de travail. Jusqu'au $\mathrm{xx}^{\mathrm{e}}$ siècle, monter à cheval ou marcher étaient les seuls moyens de transport sur le terrain accidenté de l'Islande. Le patrimoine matériel et immatériel lié aux chevaux est donc fort dans le pays. Ce patrimoine s'est avéré important pour les entreprises de tourisme équestre en Islande, mais son rôle dans le développement des activités de loisirs des touristes domestiques n'a pas encore été étudié. Cette recherche se penche sur le rôle du patrimoine immatériel et matériel dans les expériences des touristes domestiques équestres itinérants, c'est-à-dire pratiquant des randonnées équestres de plusieurs jours, en groupe, sur leurs propres chevaux. La recherche a été menée à travers une combinaison d'observations participantes, de 11 entretiens et de récits auto-ethnographiques relatifs au fait d'être un touriste à cheval en Islande. Nos résultats tendent à démontrer que le patrimoine matériel et immatériel lié aux chevaux se traduit par des activités de tourisme équestre, pour lesquelles suivre les traces de ses ancêtres le long des sentiers historiques s'avère important pour les pratiquants. Le patrimoine équestre est ainsi vécu et développé pour les générations actuelles et futures d'hommes et de chevaux.

\section{INDEX}

Mots-clés: touristes domestiques, longues randonnées à cheval, patrimoine équestre, loisirs, sentiers équestres

Keywords: domestic tourists, long riding tours, horse heritage, leisure, riding trails

\section{AUTHORS}

\section{GUĐRÚN HELGADÓTTIR}

Professor

Department of Business and IT

USN School of Business, Norway and Department of Rural Tourism, Hólar University, Iceland gudrun.helgadottir[at]usn.no

\section{INGIBJÖRG SIGURĐARDÓTTIR}

Assistant Professor

Rural Tourism Department, Hólar University, Iceland

inga[at]holar.is 